\title{
Hagnýting persónuupplýsinga á Facebook hjá eftirlitsstofnunum
}

\author{
Sigurður G. Hafstað, lögfræðingur og stjórnsýslufræðingur, Sýslu- \\ maðurinn á höfuðborgarsvæðinu \\ Jóhanna Gunnlaugsdóttir, prófessor við Félags- og mannvísindadeild \\ Háskóla Íslands
}

\begin{abstract}
Útdráttur
Markmið rannsóknarinnar var að kanna hvernig upplýsingar, sem aflað var á Facebook, væru nýttar við opinbert eftirlit með einstaklingum hér á landi. Tilgangur rannsóknar var meðal annars að varpa ljósi á formlega og óformlega notkun slíkra upplýsinga og greina umfang hennar. Við rannsóknina voru tekin hálfstöðluð viðtöl við sérfræðinga sem störfuðu hjá tilteknum úrskurðar- eða eftirlitsstofnunum. Đá átti sér stað greining á stjórnvaldsúrskurðum til pess að kanna hvernig stofnanir byggðu ákvarðanir á upplýsingum sem aflað var á Facebook. Niðurstöður rannsóknarinnar sýndu að upplýsingar á Facebook hafa verið nýttar við opinbert eftirlit hér á landi. Slíkar upplýsingar hafa verið formleg ákvörðunarástæða í einhverjum tilvikum. Đá kom í ljós að stofnanir, sem tóku pátt í rannsókninni, höfou einnig nýtt upplýsingar með óformlegum hætti meðal annars til pess að fá betri tilfinningu fyrir tilteknum málum, bera kennsl á einstaklinga, afla upplýsinga um ferðir peirra, eða til pess að hafa uppi á fólki.
\end{abstract}

Efnisorð: Facebook; rafrænt eftirlit; samfélagsmiðlar; opinber stjórnsýsla.

\author{
Icelandic Review of Politics and Administration Vol. 12, Issue 2 (343-368) \\ (c) 2016 Contact: Sigurður G. Hafstað, sigurdurgust@gmail.com \\ Article first published online December 19th 2016 on http://www.irpa.is \\ Publisher: Institute of Public Administration and Politics, Gimli, Sæmundargötu 1, 101 Reykjavík, Iceland \\ Stjórnmál \& stjórnsýsla 2. tbl. 12. árg. 2016 (343-368) Fræđigreinar \\ (c) 2016 Tengiliður: Sigurđur G. Hafstað, sigurdurgust@gmail.com \\ Vefbirting 19. desember 2016 - Birtist á vefnum http://www.irpa.is \\ Útgefandi: Stofnun stjórnsýslufræđa og stjórnmála, Gimli, Sæmundargötu 1, 101 Reykjavík \\ DOI: http://dx.doi.org/10.13177/irpa.a.2016.12.2.8 \\ This work is licensed under a Creative Commons Attribution 4.0 License.
}




\title{
The Utilization of Personal Data on Facebook by Surveil- lance Authorities
}

\begin{abstract}
The aim of this research was to explore how information on Facebook was being used by surveillance authorities in Iceland. The objective was to explore both formal and informal use of such information. Semi structured interviews were conducted with specialists who were employed at surveillance authorities in Iceland. In addition the research contains legal analysis on administrative decisions to explore the formal use of such information. Findings showed that information on Facebook has been utilized in surveillance. Governmental authorities have based formal decisions on such information. This type of information has also been regularly used in more informal ways such as to get a better feeling for a particular case. Other authorities reported to have used Facebook to identify individuals, gather information on their whereabouts or location.
\end{abstract}

Keywords: Facebook; electronic surveillance; social media; public governance.

\section{Inngangur}

Almenningur opinberar gífurlegt magn persónuupplýsinga á samfélagsmiðlum. Facebook er sá samfélagsmiðill sem hlotið hefur mesta útbreiðslu á alpjóðavísu (Már Einarsson \& Jóhanna Gunnlaugsdóttir 2014) og ýmis stjórnvöld hafa tekið samfélagsmiðilinn í pjónustu sína með margvíslegum hætti (sjá til dæmis Barker, Barker, Bormann \& Neher 2013; Orsburn 2012). Við skoðun á peim upplýsingum sem par er að finna, er ljóst að möguleg notkun samfélagsmiðilsins við opinbert eftirlit sé mikil.

Friðhelgi einkalífs er talið til grundvallarréttinda í lýðræðispjóðfélagi. Slík friðhelgi getur pó aldrei verið takmarkalaus. Örar tækniframfarir á sviði upplýsingatækni hafa óumflýjanlega áhrif á möguleika til eftirlits og gagnasöfnunar. Pá verður ekki hjá pví komist að skoða hugtök á borð við einkalíf og einkalífsvernd í ljósi upplýsingasamfélags 21. aldar.

Ekki er útilokað að íslensk stjórnvöld eigi pess kost að nýta samfélagsmiðla enn frekar en nú er gert við opinbert eftirlit innan marka gildandi laga. Parna vegast á andstæð sjónarmið um hagkvæma og skilvirka stjórnsýslu annars vegar og persónuvernd og friðhelgi einkalífs hins vegar. Til pess að hægt sé að komast að niðurstöðu parf fyrst að fara fram greining á framkvæmd og umfangi umrædds eftirlits.

Rannsóknin, sem hér er til umfjöllunar, var unnin í tengslum við verkefnið Valds- og lýdrađisrannsókn Félagsvisindasvids Háskóla Íslands á vormisseri 2016 (Sigurður G. Hafstað 2016). Markmið greinarinnar er að kynna nokkrar helstu niðurstöður rannsóknarinnar, pað er öflun og meðferð persónuupplýsinga á Facebook við opinbert eftirlit hjá tilteknum stjórnsýslustofnunum. Gagna var aflað með eigindlegum aðferðum; (1) viðtölum við lögmenntaða starfsmenn hjá fjórum stofnunum sem sinntu opinberu eftirliti 
og/eða úrskurðarvinnu og (2) fyrirliggjandi opinberum úrskurðum. Helstu niðurstöður voru pær að allar stofnanirnar höfðu notað upplýsingar, sem aflað var á Facebook, í störfum sínum og allar höfðu pær aflað upplýsinganna að eigin frumkvæði.

Í upphafi greinarinnar er fræðilegum bakgrunni gerð skil og pví næst fjallað um aðferðafræði rannsóknarinnar. Niðurstöður eru settar fram í aðskildum köflum og síðan birtast umræður og samantekt um rannsóknina.

\section{Fræđilegur bakgrunnur um samfélagsmiðla og eftirlit}

Fræðigreinin eftirlitsfræði (surveillence studies) snýst um eðli og framkvæmd hvers konar eftirlits. Að mati Lyon (2007) telst hún til pverfræðilegra félagsvísinda meðal annars á sviði laga og upplýsingatækni og slíkar rannsóknir leggja grunninn að „empirískum“ rannsóknum og skapa tækifæri til mótunar kenninga á sviðinu.

Erfitt getur reynst að skilgreina hugtakið eftirlitsstarfsemi með tæmandi hætti. Hugtakið eftirlit hefur verið skilgreint sem kerfisbundin, afmörkuð og regluleg eftirtekt með einstaklingsbundnum atriðum með раð að leiðarljósi að hafa áhrif á, stjórna og/eða vernda pá sem eftirtektin beinist að. Með reglubundnu eftirliti er átt við að pað sé ekki einungis háð tilviljun eða fari einungis fram með sjálfvirkum hætti. Eftirlit er hins vegar framkvæmt vísvitandi og með skilgreindum aðferðum. Í fræðilegri umfjöllun getur haft pýðingu að gera greinarmun á hlutlausu eftirliti sem getur til dæmis falist í ummönnun barna og sjúklinga og annars konar eftirliti sem fer fram í tengslum við beitingu opinbers valds (Almer, Fuchs, Kreilinger \& Sevignani 2014).

Eftirlit getur tekið á sig margar myndir. Баð getur átt sér stað með „,fýsískri““ eftirgrennslan svo sem með vettvangsheimsóknum eða skýrslutökum. Pá getur eftirlit einnig farið fram með rafrænum hætti enda gerir nútímatækni mönnum kleyft að varðveita, vinna, greina og samkeyra nær ótakmarkað magn upplýsinga. Eftirlitsaðferðir, sem fela í sér aðgerðir af slíkum toga, hafa að einhverju leyti tekið við af „fýsískri“ eftirgrennslan (Haggerty, Wilson \& Smith 2014).

Notkun öryggismyndavéla hefur verið rannsökuð ítarlega. Samkvæmt eldri rannsókn, sem gerð var á umfangi rafrænnar vöktunar í Bretlandi, kom fram að öryggismyndavélar taka að meðaltali prjú hundruð ljósmyndir eða myndskeið af meðal Lundúnarbúa á degi hverjum (Cockfield 2002). Tölfræðilegar rannsóknir hafa verið gerðar á fylgni notkunar á eftirlitsmyndavélum og glæpatíðni (Welsh \& Farrington 2008). Pá hafa verið gerðar ýmsar rannsóknir á framkvæmd og próun sértækari vöktunar til dæmis á notkun öryggismyndavéla við umferðareftirlit (Kammerer 2009).

Söfnun Facebook á persónuupplýsingum hefur verið töluvert í umræðunni. Viðskiptamódel Facebook byggist einmitt á varðveislu, vinnslu, greiningu og endursölu upplýsinga um notendur miðilsins í markaðstilgangi (Fuchs 2011).

рá hefur nokkuð verið fjallað um upplýsingamiðlun Facebook til stjórnvalda í págu öryggis og refsivörslu. Frá árinu 2013 hefur Facebook birt tölfræðiupplýsingar um fjölda upplýsingabeiðna frá stjórnvöldum um tiltekna notendur. Nýjustu upplýsingar eru frá desember 2015. Samkvæmt upplýsingum frá Facebook hefur slíkum beiðnum fjölgað jafnt og pétt á heimsvísu. Upplýsingabeiðnir frá stjórnvöldum voru 41.214 á seinni hluta 
ársins 2015 en voru einungis 35.051 á sama tíma fyrir árið 2014. Pví er um 18\% hækkun að ræða á tímabilinu. Athyglisvert er að sjá að frá árinu 2013 hafa sex slíkar beiðnir borist frá íslenskum stjórnvöldum (Facebook 2016)

Nokkuð hefur verið fjallað um tilvik par sem eftirlitsaðilar afla sjálfir upplýsinga um einstaklinga á Facebook til dæmis í tengslum við mannaráðningar (Spraque 2008). Dá viðhafa atvinnurekendur eftirlit með hegðun starfsfólks á netinu í auknum mæli. Slíkt getur meðal annars átt sér stað með pví að yfirmaður skyldar undirmann til pess að sampykkja „vinarbeiðni“ á Facebook með pað fyrir augum að leita upplýsinga á lokuðum „prófíl“. Rannsókn sem birtist í American Buisness Law Journal 2012 sýndi fram á að 18\% pátttakenda voru „vinir“ yfirmanns síns á Facebook. Pá eru pess dæmi að atvinnurekendur fari fram á að starfsmenn veiti aðgang að lokuðum Facebook-síðum (Abril, Levin \& Del Riego 2012).

pegar upplýsingar, sem almenningur birtir á samfélagsmiðlum eru skoðaðar nánar, má sjá að möguleg notkun peirra í eftirliti er mikil. Um leið og notandi skráir sig á samfélagsmiðil setur hann fram margvíslegar persónuupplýsingar um sjálfan sig svo sem um aldur, kyn, búsetu, hjúskaparstöðu, menntun, starf og áhugamál. Pessar upplýsingar mynda síðan „prófíl“ notandans. Auk pessa gera flestir samfélagsmiðlar notendum kleift að birta eða deila öðru efni af persónulegum toga svo sem ljósmyndum (Ellison \& Boyd 2014).

Facebook hefur fengið mesta útbreiðslu hérlendis pegar kemur að samfélagsmiðlum (Jóhanna Gunnlaugsdóttir 2014). Facebook er persónubundinn samfélagsmiðill enda skyldar hann notendur til opinberrar auðkenningar. Notendaskilmálar Facebook kveða á um að óheimilt sé að beita blekkingum vísvitandi til pess að hafa áhrif á ímynd svo sem ranga tilgreiningu aldurs eða röng eða villandi tengsl við aðra einstaklinga eða lögpersónur. Rafræn ímynd notandans er pannig í efnislegum tengslum við persónu hans. Petta leiðir af sér að bæði tengdir og ótengdir aðilar geta nálgast umtalsvert magn upplýsinga um Facebook-notendur svo sem nöfn, andlitsmyndir og upplýsingar um sameiginlegar tengingar (Lewis, Kaufman \& Christakis 2008).

Fjallað hefur verið um Facebook í tengslum við hið opinbera svið mannlífs sem fer alfarið fram á rafrænum vettvangi (digital public sphere). Rannsóknir benda til pess að tilkoma Facebook hafi haft áhrif á hugmyndir manna um mörk opinberra upplýsinga og einkalífs (Bjarki Valtýsson 2012). Pá sýna rannsóknir fram á að fólk upplifi í auknum mæli ótta við að telja sig ósýnilegt á samfélagsmiðlum (Bucher 2012).

Samkvæmt Debatin, Lovejoy, Horn og Hughes (2009) er rík tilhneiging hjá einstaklingum um að birta gífurlegt magn persónuupplýsinga á samfélagsmiðlum pótt pví fylgi aukin hætta á misnotkun af hendi priðja aðila. Öryggishegðun Facebook-notenda hefur verið sérstaklega rannsökuð. Athugun á nethegðun nemenda við Harvard-háskóla gefa til kynna að öryggishegðun einstaklinga á Facebook ráðist af félagslegum og persónulegum páttum. Pá séu bein jákvæð tengsl milli aukinnar Facebook-notkunar og aukinnar öryggishegðunar á Facebook (Lewis, Kaufman \& Christakis 2008). Aðrar rannsóknir leiða í ljós að peir, sem telja sig hafa orðið fyrir brotum á eigin friðhelgi, séu líklegri en aðrir til pess að viðhafa strangari friðhelgisstillingar (Debatin, Lovejoy, Horn \& Hughes 2009). 
Afstaða manna til trúverðugleika upplýsinga á samfélagsmiðlum hefur verið könnuð. Rannsókn meðal 400 spænskra blaðamanna, á vegum Háskóla Carlos III í Madrid, leiddi í ljós að 67\% pátttakenda töldu að upplýsingar, sem aflað var á samfélagsmiðlum, væru óáreiðanlegri en pær sem aflað var eftir hefðbundnari leiðum (Curiel 2013). Í Bandaríkjunum hafa lögfræðingar fjallað um notkun löggæslustofnanna á samfélagsmiðlum í refsivörsluskyni og bent hefur verið á mögulega nauðsyn pess að endurskoða hugmyndir manna um rétt til einkalífsverndar með tilliti til tækniframfara (Strandburg 2011).

Erfitt getur reynst að fjalla um opinbert eftirlit án pess að víkja lauslega að peim lagaramma sem um pað gildir. Hér gefst ekki rúm til pess fjalla með ítarlegum hætti um efnið út frá lögfræðilegu sjónarmiði. Pó verður vart hjá pví komist að nefna nokkur atriði. раð leiðir af lögmætisreglu stjórnsýsluréttar að aðgerðir stjórnvalda verða að byggjast á sérstakri lagaheimild. Dá eru stjórnvöld almennt bundin af málsmeðferðareglum stjórnsýslulaga nr. 37/1993 í störfum sínum. Notkun persónuupplýsinga í eftirlitsskyni getur einnig fallið undir gildissvið laga nr. 77/2000 um persónuvernd og meðferð persónuupplýsinga, hér eftir nefnd persónuverndarlög. Hvenær og með hvaða hætti stjórnvöldum er heimilt að stunda eftirlit, getur ráðist af skýringu á peirri lagaheimild sem eftirlit grundvallast á. Đá verður eftirlitið ávallt að samræmast meginreglum stjórnsýsluréttar á borð við meðalhóf og lögmæti. Hvort og að hvaða marki stjórnvöldum er heimilt að líta til upplýsinga á Facebook við opinbert eftirlit getur einnig ráðist af túlkun pess hvort umræddar upplýsingar teljist opinberar. Að öðrum skilyrðum uppfylltum getur stjórnvaldi verið heimilt að vinna með viðkvæmar persónuupplýsingar sem hinn skráði hefur sjálfur gert opinberar sbr. 6. tl. 1. mgr. 9. gr. persónuverndarlaga. Ákvæðið byggist á peirri grunnreglu að hver maður ráði yfir upplýsingum um sjálfan sig. Í pví felst ákvörðun einstaklinga varðandi hvaða upplýsingum er deilt og hvaða upplýsingum einstaklingar halda fyrir sig (Sigrún Jóhannesdóttir 2015). Umfjöllun um lagalegar heimildir til vinnslu og varðveislu persónupplýsinga er viðamikið og verðugt rannsóknarefni sem fellur pó að mestu utan við efnistök pessarar greinar.

Eins og fram hefur komið stundar Facebook gífurlega söfnun og vinnslu persónuupplýsinga í markaðsskyni. Đá hefur Facebook miðlað upplýsingum um notendur sína til löggæsluyfirvalda í einhverjum tilvikum. Unnt er að halda pví fram að pess konar eftirlit eigi sér stað á efsta stigi (macro-stigi). Rannsóknir sýna enn fremur fram á að stjórnvöld hafa einnig notað Facebook við eftirlit á lægra stigi (micro-stigi) svo sem til pess að afla upplýsinga við innra eftirlit og við mannaráðningar. Segja má að viðfangsefni pessarar rannsóknar lúti að eftirliti stjórnvalda á lægra stigi. Rannsókin felst í pví að kanna umfang og eðli upplýsinganotkunar á Facebook hjá hérlendum eftirlitsstofnunum. Rannsókn pessari er fyrst og fremst ætlað að veita vísbendingar um hvernig og hvenær stjórnvöld hér á landi afla og skrá persónuupplýsingar sem fengnar eru af Facebook-síðum almennings. Pá er tilgangur rannsóknarinnar að veita vísbendingar um hvernig notkun umræddra upplýsinga er háttað í stjórnsýslulegu tilliti hvort sem slík notkun fer fram með formlegum eða óformlegum hætti. Ekki er vitað til pess að slík rannsókn hafi verið framkvæmd með peim hætti og hér er gert. 


\section{STJÓRNSÝSLA}

\section{Aðferðafræði}

Rannsóknin var gerð á vormisseri 2016. Markmið hennar var að skoða umfang og eðli notkunar upplýsinga á Facebook varðandi opinbert eftirlit með einstaklingum á Íslandi. Rannsóknarspurningar vörðuðu:

- Hvort upplýsingar á Facebook væru nýttar við opinbert eftirlit hérlendis.

- Hvers konar upplýsingar væru nýttar og hvernig notkun peirra væri háttað.

Í pessu samhengi snerust rannsóknarspurningarnar fyrst og fremst um hlutrænar staðreyndir, pað er hvort og hvernig stjórnvöld hafa nýtt sér upplýsingar á Facebook við opinbert eftirlit hérlendis.

Notast var við eigindlega aðferðafræði (qualitative methodology) við framkvæmd rannsóknarinnar. Slík nálgun hentar vel pegar skoða á viðhorf og reynslu viðmælenda um félagslegar athafnir (Hennink, Hutter \& Bailey, 2011; Silverman, 2013). Í fyrsta lagi var gögnum safnað með viðtalsaðferð (interview method) og tekin voru hálfopin viðtöl (semistructured inverviews) við starfsfólk tiltekinna stofnanna (Helga Jónsdóttir 2013). Petta voru fagleg samtöl par sem leitast var við að fá viðmælendur til pess að tjá reynslu sína og sjónarmið um pað efni sem var til skoðunar (Braun \& Clarke 2013). Í öðru lagi var upplýsinga aflað úr ytra umhverfi pessara stofnanna og pær nýttar við gerð rannsóknarinnar (Saunders, Lewis \& Thornhill 2009). Dessar upplýsingar voru einkum lög og reglugerðir sem vörðuðu starfsemi stofnananna. Loks, í priðja lagi voru stjórnsýsluúrskurðir, sem snertu efnistök rannsóknarinnar, greindir.

Viðtöl voru tekin við fjóra lögmenntaða starfsmenn hjá jafnmörgum stofnunum sem sinntu eftirliti og/eða úrskúrðarvinnu á sviði persónulegrar hegðunar einstaklinga. Valið var kerfisbundið (purposive sampling) (Katrín Blöndal \& Sigríður Halldórsdóttir 2013; Palys 2008) og notast var við „gervinöfn“ til pess að virða trúnað (Gorman \& Clayton 2005). Stofnanunum voru einfaldlega gefin nöfnin Stofnun A, Stofnun B, Stofnun C og Stofnun D.

Með fjölpættri nálgun (triangulation) við framkvæmd rannsóknarinnar var leitast við að stuðla að auknu réttmæti. Að mati Schwandt (2007) er slík nálgun leið til pess að auka réttmæti rannsókna. Pannig sé hægt að draga ályktanir á grundvelli rannsóknargagna og staðreyna að tiltekin gögn styðji tiltekna skilgreiningu, staðhæfingu og svo framvegis.

Notast var við aðferð grundaðrar kenningar (grounded theory) við greiningu rannsóknargagnanna. Par er gengið út frá kerfisbundnum viðmiðum og samanburði við söfnun og greiningu gagnanna í peim tilgangi að mynda kenningar á grundvelli peirra sjálfra (Charmaz 2014; Glaser \& Strauss 1967; Schvandt 2007). Gögnin voru lesin og greind með kóðun (coding) sem fól í sér flokkun upplýsinganna. Kóðun og flokkun er forsenda pess að hægt sé að próa kenningu á grundvelli fyrirliggjandi gagna (Charmez 2014; Hennink o.fl. 2011; Unnur Guðrún Óttarsdóttir 2013). 


\section{Upplýsingar á Facebook og opinbert eftirlit}

Notkun upplýsinga á Facebook við opinbert eftirlit getur birst með ýmsum hætti. Notkun slíkra upplýsinga getur átt sér stað við eftirlit sem fer fram að frumkvæði stjórnvalds. Pá geta umræddar upplýsingar einnig verið notaðar til pess að sannreyna eða véfengja upplýsingar í máli sem hefst að frumkvæði annarra. Hér á eftir verða upplýsingar frá viðtölum og viðeigandi úrskurðum ræddar.

\section{1 Öflun, miðlun og skráning upplýsinga á Facebook}

Upplýsingar um einstaklinga á Facebook, sem grein pessi fjallar um, stafa upphaflega frá notendum sjálfum. Að pví sögðu verða stjórnvöld fyrst að komast yfir umræddar upplýsingar áður en unnt er að hagnýta pær. Í pessu skyni getur öflun upplýsinga farið fram að frumkvæði stjórnvaldsins. Pá geta stjórnvöld einnig móttekið upplýsingar frá aðilum máls, almenningi eða öðrum stjórnvöldum. Ekki er útilokað að stjórnvöld geti einnig móttekið upplýsingar um einstaklinga beint frá forsvarsmönnum Facebook, til dæmis á grundvelli dómsúrskurðar. Að pví sögðu fellur notkun slíkra upplýsinga utan efnistaka pessarar greinar. Nú verður vikið stuttlega að pví hvernig öflun upplýsinga á samfélagsmiðlum var háttað hjá stjórnvöldum. Pá verður vikið að pví hvernig móttaka, miðlun og skráning upplýsinga fór fram.

\subsection{1 Öflun upplýsinga stjórnvalda á samfélagsmidlum}

Allir viðmælendur staðfestu að peir hefðu nýtt upplýsingar, sem aflað var á Facebook, í tengslum við störf sín. Aðeins ein stofnananna fjögurra hafði opinbera Facebooksíðu. Í ljós kom hjá tveimur peirra að starfsmenn notuðust eingöngu við eigin aðgang á Facebook pegar upplýsinga var aflað um einstaklinga á samfélagsmiðlinum. Hjá öðrum stofnunum notuðu starfsmenn ýmist eigin aðgang eða sérstakan aðgang sem hafði verið stofnaður sérstaklega í pessu skyni. Fram kom hjá Stofnun B að ein ástæða pess að sumir starfsmenn notuðust við eigin aðgang væri að öllum líkindum til hægðarauka:

Ég held að pað sé misjafnt. Ég held að fólk sé jafnvel á sínum aðgangi stundum. Раð hlýtur að vera mjög algengt hjá pessum stofnunum pví menn eru kannski ekki að setja sig í pessar stellingar að nú er ég að slá mig út hér og slá sig svo inn.

Séraðgangur til upplýsingaöflunar hafði verið stofnaður með petta fyrir augum hjá Stofnun C. Dar höfðu farið fram umræður innanhúss um notkun mismunandi Facebook-aðgangs og starfsmenn voru sammála um að einfaldast væri að notast við séraðgang í pessum tilgangi:

Баð hefur verið stofnaður séraðgangur fyrir pá sem eru að skoða petta en ég pori ekki að fullyrða fyrir alla. Ég sjálf nota bara minn oftast. En ég hef líka farið inn á hinn en við höfum líka rætt pað að vera bara með séraðgang, pað er langpægilegast. 
pá kom fram að sumum starfsmönnum stofnunarinnar pætti ópægilegt að afla upplýsinga á eigin Facebook-aðgangi: „Fólki finnst pað mis, sumum finnst pað ópægilegt að fara inn á sínu." Hjá viðmælanda komu fram sjónarmið um hver gæti verið eiginlegur eigandi Facebook-aðgangs og hugmyndir um að greinarmunur gæti falist í pví hvort öflun færi fram á séraðgangi stofnunar eða öðrum aðgangi sem starfsmenn stofnuðu sérstaklega í pessu skyni:

Рað skiptir ekki máli hvort pau séu með sér eða stofnunin á einhvern enda á stofnunin hann ekkert. एað er bara einhver hér innanhús sem myndi bara stofna hann og hann heita bara einhverju nafni pá er maður líka að búa til gervimanneskju sem mér finnst svona ... svo er pað líka eitt sjónarmið, alls konar pælingar í kringum petta.

\subsubsection{Móttaka upplýsinga frá adilum máls}

Allir pátttakendur höfðu móttekið upplýsingar, sem aflað var á Facebook, frá almennum borgurum. Hjá premur stofnananna kom fram að stofnunin hefði móttekið upplýsingar, sem aflað var á Facebook, frá aðilum máls. Í ljós kom hjá Stofnun A að móttaka slíkra upplýsinga gæti átt sér stað í úrskurðarmálum milli tveggja aðila: „Aðilar sjálfir eru að leggja fram einhverjar upplýsingar sem aflað var á Facebook og hugsanlega upplýsingar sem peir eru að afla um hinn aðilann, eftir peim leiðum.“ Enn fremur kom í ljós að í einhverjum tilvikum gætu pess háttar gögn hafa verið ákvörðunarástæða enda vísað í pau í skriflegum ákvörðunum:

Баð kann að vera að einhverjar upplýsingar sem aðili sjálfur hafi lagt fram séu ákvörðunarástæða ... Í peim skriflegu ákvörðunum, sem hér er verið að búa til, á að rekja málsatvik og gagnaöflun og allt pað pannig að pað er eiginlega, ef á annað borð er verið að leggja fram svona gagn, er einhver umfjöllun um pað. Eg pori ekki alveg að fullyrða um раð.

Í viðtali hjá Stofnun A var framlagning umræddra upplýsinga frá aðilum almennt á pappírsformi. Pær gátu síðan orðið formlegur hluti af mál við framlagningu upplýsinga:

Öll gögn sem eru lögð fram hérna eru á pappír. [...] Ef pú ert að leggja fram í máli hér upplýsingar á Facebook parftu að byrja að prenta pær út, eða koma peim á pappír eða gera einhverjar slíkar ráðstafanir. Síðan leggurðu pappírinn fram, pá verður pappírinn hluti af málinu eða skannað eintak eftir atvikum, en hér er ekki verið að leggja fram rafræna skrá.

Viðmælandi hjá Stofnun C nefndi að líklega hefðu Facebook-samskipti verið lögð fram hjá stofnuninni: 


\section{STJÓRNMÁL \& \\ STJÓRNSÝSLA}

Já við höfum fengið framlögð samskipti. Nú pori ég ekki alveg að fullyrða hvort pað hafi verið á Facebook. Við höfum fengið Skype chat-samtöl. Jú, við höfum örugglega fengið Facebook-samtöl líka. Ég er svona 99\% viss um að við höfum fengið Facebook-samtöl lögð fram til að sýna fram á...

Viðmælandi hjá Stofnun D tiltók að upplýsingar, sem aflað hafði verið á Facebook, hefðu verið lagðar fram af aðilum máls til pess að sýna fram samskipti milli einstaklinga: „Fólk hefur líka lagt slíkt fram, aðallega til að styrkja sinn málsstað um einhver samskipti, segjum á milli forsjáraðila sem eru í einhverjum átökum." Hins vegar kom fram hjá pessum viðmælanda að algengara var að smáskilaboð úr farsímum væru lögð fram af aðilum máls fremur en samskiptasaga peirra á Facebook.

\subsubsection{Móttaka upplýsinga frá almenningi}

Eins og áður hefur komið fram höfðu allar stofnanirnar móttekið upplýsingar, sem aflað var af Facebook, frá almennum borgurum. Drjár peirra höfðu enn fremur móttekið upplýsingar frá almennum borgurum pað er að segja, borgurum öðrum en aðilum máls. Um skjáskot var að ræða í öllum tilvikum. Stofnun C hafði i að minnsta kosti einu tilviki móttekið upplýsingar, sem aflað var á Facebook, í bréfpósti:

Ég man eftir máli par sem okkur bárust upplýsingar, screenshot af Facebook, sem einhver sendi hérna inn. Par var handskrifað við pað að pað væri eitthvað ekki allt 1 lagi og petta var pess eðlis að við töldum að við pyrftum að bregðast við, eitthvað sem við höfðum ekki skoðað áður. Рað voru auðvitað upplýsingar á Facebook en við öfluðum peirra ekki. Um móttöku og vinnslu umræddra upplýsinga kom fram: Detta í raun kom í pósti og inn til skjalavarða og var svo sent til peirra sem voru með málið upphaflega hjá pessum umsækjendum.

Stofnun B hafði móttekið umræddar upplýsingar frá almenningi, pað er öðrum en aðilum máls. Stofnunin byggði aftur á móti ekki ákvarðanir sínar einvörðungu á pess konar upplýsingum:

Við erum í raun að keyra á sömu reglu með ábendingar sem við fáum, ábending frá pér til mín um að einhver sé að stunda ... yrði aldrei grundvöllur fyrir ákvörðun. Рað getur verið grundvöllur fyrir pví að opna mál og skoða nánar en ábendingar um að pessi sé að gera petta, eru pá bara gögn í málinu ef pað verður að einhverju máli.

Viðmælandi hjá Stofnun D nefndi að eitthvað væri um móttöku upplýsinga, sem aflað var á Facebook, í formi tilkynninga frá almenningi. Álíka sjónarmið komu fram um að stofnunin byggði ákvarðanir sínar ekki eingöngu á pess háttar upplýsingum: 
Við fáum mögulega einhver skjáskot inn sem tilkynningar. Á grundvelli pess getur verið tekin ákvörðun um að kanna mál sem er náttúrulega ákvörðun. Ég man samt ekki eftir slíkri tilkynningu, að рað hafi verið einvörðu horft til pess, en mögulega hefur pað líka verið gagn í máli. ... við fáum tilkynningu eða sjáum pað sjálf að pað var ástæða til að bregðast við og pað fór fyrir ... en pað var fyrir mál í gangi og ... úrskurðaði um ákveðna hluti á grundvelli pess sem við sáum á Facebook.

\subsubsection{Móttaka upplýsinga frá stjórnvöldum}

Einungis ein stofnananna fjögurra hafði „mögulega“ móttekið upplýsingar, sem aflað var á Facebook, frá öðru stjórnvaldi. Viðmælandi hjá Stofnun D sagði:

Nei ég man ekki eftir pví. Mögulega pegar pú segir pað, pá var pað kannski einhvern tíma einhver sem var með skjáskot af ... en hver pað var, örugglega ekki sýslumaður. Ef pað er pá er pað ekki algengt, ekki frá skólum, hvort pað var skóli í pessu tilviki, pað er alla vega ekki algengt, ekki að mér vitanlega alla vega.

\subsubsection{Midlun upplýsinga til annarra stjórnvalda}

Viðmælendur tveggja stofnananna könnuðust við að hafa miðlað upplýsingum, sem aflað hafði verið á Facebook, áfram til annars stjórnvalds. Hjá Stofnun $C$ var pessum upplýsingum miðlað til lögreglu. Баð var gert í peim tilvikum pegar stofnunin hafði kært tiltekin mál sem til meðferðar voru. Viðmælandi Stofnunar A sagði að stofnunin hefði miðlað upplýsingum til annars stjórnvalds. Par komu fram sjónarmið um hvort pannig miðlun ætti sér alltaf stað í nafni stofnunar eða mögulega í nafni einstakra starfsmanna:

Já, svo getur maður líka verið í smá ... Maður veltir pví fyrir sér hvort maður sé pá að starfa sem stjórnvald eða er maður bara einstaklingur sem rekst á upplýsingar sem maður veit að eiga að fara til annars stjórnvalds ... Ég hef tilkynnt til barnaverndar eitthvað sem ég hef séð á Facebook.

Viðmælandi hjá Stofnun B kannaðist ekki við að upplýsingum, sem aflað hafði verið á Facebook, hefði verið miðlað til annars stjórnvalds í págu eftirlits: „Ekki í einhverjum eftirlitstilgangi. Pegar ákvörðun er kærð eða eitthvað slíkt eru náttúrulega öll gögn send áfram til ... Рað getur bó vel verið að petta hafi átt sér stað.“ " hefði pess háttar miðlun átt sér stað hefði eitthvað meira legið par að baki en einungis upplýsingar á Facebook: „Nei, ég man ekki eftir tilviki par sem við sendum ábendingu til ... ég veit ekki skattstjóra eða ... bara á Facebook. Баð hefur pá legið eitthvað meira á bak við pað.“ Viðtalið hjá Stofnun D leiddi í ljós að par var ekki kannast við að upplýsingum, sem fengist höfðu á Facebook, hefði verið miðlað til annars stjórnvalds. 


\section{STJÓRNMÁL \& \\ STJÓRNSÝSLA}

\subsubsection{Skráning upplýsinga}

Allir viðmælendur svöruðu pví játandi að hafa varðveitt upplýsingar sem aflað var á Facebook. Hjá öllum stofnununum voru umræddar upplýsingar varðveittar í prentuðu formi með gögnum fyrirliggjandi mála.

Stofnun A varðveitti slíkar upplýsingar aðeins pegar um var að ræða framlögð gögn frá viðeigandi aðilum: „Já, upplýsingar sem aðilarnir að pessu máli eru að leggja fram. Öll gögn sem eru lögð fram hérna eru á pappír.“ Stofnun B varðveitti upplýsingar, sem aflað var á Facebook, sem máli skiptu fyrir úrlausn máls: „Já, pað er bara nauðsynlegt. †á reynum við að geyma bara pau gögn sem skipta máli. Við erum ekki að prenta út Facebook-síðu viðkomandi mörg ár aftur í tímann, bara einstakar færslur og pað sem málinu viðkemur."

Stofnun C varðveitti upplýsingar sem nýttar voru á formlegan hátt: „Já, ef verið hefur að nota pað ... Баð er pá pannig að fólk er boðað í viðtal og peim er sýnt, petta er hérna opið hjá pér, og borið undir pað ... Đá er pað náttúrulega hluti af málinu.“

Í einhverjum tilvikum varðveitti Stofnun D Facebook-upplýsingar með gögnum máls. Stofnunin varðveitti einnig flest pau gögn sem unnið hafði verið með. Ákveðin sjónarmið um meðalhóf við varðveislu slíkra upplýsinga kom fram: „Ðað er bara sett inn í dagatal sem er bara ákveðið vinnugagn. Við geymum til dæmis útprent af svona sms sem fólk kemur með ... Við viljum frekar hafa meira en minna en við verðum náttúrulega að gæta meðalhófs líka.“

Engin stofnun kannaðist við að varðveita upplýsingar frá Facebook annars staðar en í gögnum máls. Viðmælandi hjá Stofnun C sagði: „Nei, við erum ekki með einhverja Facebook-möppu eða eitthvað svoleiðis. Ég man ekki heldur eftir pví að við sendum neitt á milli í tölvupósti ef petta er hluti af rannsókninni ... Pá er petta prentað út og borið undir eða sent fólki.“

Viðmælandi hjá Stofnun B útilokaði ekki að Facebook-upplýsingar kynnu að hafa verið sendar á milli með tölvupósti: „Фað getur náttúrulega verið að eitthvað af pessu fari á milli í tölvupóstum, sem er náttúrlega geymt hjá okkur, að öðru leyti, nei.“

\subsection{Formleg notkun upplýsinga}

Hér á eftir fer samantekt um formlega notkun upplýsinga sem aflað hefur verið á Facebook í págu opinbers eftirlits. Í pví skyni verður litið til atvika par sem sérstakt stjórnsýslumál var hafið, pví lokið eða byggt á slíkum upplýsingum við formlega ákvörðunartöku.

\subsubsection{Upphaf stjórnsýslumáls}

Hjá premur stofnananna var kannast við að hafin hefði verið rannsókn á grundvelli Facebook-upplýsinga. Dess háttar rannsókn hefði síðan leitt til pess að í kjölfarið hefði formlegt stjórnsýslumál verið stofnað. Hjá Stofnun D kom fram að sennilega hefðu Facebook-upplýsingar einar og sér ekki orðið til pess að mál yrði stofnað: „Við fáum mögulega einhver skjáskot inn sem tilkynningar. Á grundvelli pess getur verið tekin 
ákvörðun um að kanna mál sem er náttúrulega ákvörðun. Ég man samt ekki eftir slíkri tilkynningu, að pað hafi verið einvörðu horft til pess en mögulega hefur pað líka verið gagn í máli.“"

Í viðtali hjá Stofnun C kom í ljós að upplýsinga væri almennt ekki aflað nema viðkomandi væri með mál í gangi:

Ég man eftir svoleiðis en ég man ekki í fljótu bragði eftir, enda erum við ekki að skoða fólk á Facebook nema pað sé með mál í vinnslu á annað borð. Við erum ekki bara að fletta, nú er pessi með mál eða ekki með mál. Við höfum bara engan tíma til pess. Раð pyrfti eiginlega alltaf eitthvað annað að koma fyrst til að við færum að skoða petta.

Í viðtalinu kom einnig fram að stofnunin stundaði ekki virkt frumkvæðiseftirlit á Facebook:

Já, við förum ekki, nei, ég held að pað geri pað engin hér. Við höfum ekki tíma til pess heldur. Við erum öll bara hérna í málunum par sem parf að halda vinnslunni gangandi. Hér er alltaf einhver vinnsla í gangi. Раð er enginn sem myndi fara með einhvern lista og segja, nú ætla ég að kíkja á petta, nei, og mér fyndist pað ekki eðlilegt.

Stofnunin hafði aftur á móti aflað upplýsinga á Facebook í kjölfar tilkynninga eða stöðubreytinga hjá viðkomandi aðila:

Раð kemur eitthvað inn. Við getum til dæmis fengið tilkynningar frá lögreglu um að pað sé ástæða fyrir okkur að skoða eitthvað, til dæmis dómar eða eitthvað svoleiðis, eða einhverjar aðrar tilkynningar og pá fáum við stöðubreytingar frá Pjóðskrá, hjúskaparbreytingar. Pá skoðum við mál.

एá kom í ljós að stofnunin hefði óskað eftir atbeina lögreglu til pess að rannsaka tiltekin atriði á grundvelli grunsemda sem byggðar voru Facebook-upplýsingum í einhverjum tilvikum:

Ég eiginlega fullyrði aldrei eitt og sér en við höfum óskað eftir pví að lögregla fari á heimili til að rannsaka búsetu fólks pví við purfum að vita, við purfum að rannsaka ... Petta er eina tækið sem við höfum til að vita hvort fólk búi saman. Degar við spyrjum segir fólk alltaf „,jä“ og fólk er með skráð sama lögheimili.

Finna má tilvik um að stjórnvöld hafi byrjað sérstakt mál á grundvelli Facebook-upplýsinga í opinberum úrskurðum. Í úrskurði Úrskurðarnefndar atvinnuleysistrygginga og vinnu- 
markaðsaðgerða 25. nóvember 2014 (19/2014) var mat nefndarinnar að ráðið yrði af Facebook-færslum kæranda að hún hefði verið við störf sem ljósmyndari, samhliða töku atvinnuleysisbóta, án pess að tilkynna um pað til Vinnumálastofnunar. Á grundvelli pess yrði að telja að kærandi hefði brugðist trúnaðar- og upplýsingaskyldum sínum gagnvart Vinnumálastofnun í ljósi peirra gagna sem fyrir liggja í málinu og tekin voru af Facebook-færslum kæranda.

\subsubsection{Niđurfelling stjórnsýslumáls}

Hjá engri stofnananna var kannast við að formlega hefði mál verið fellt niður á grundvelli Facebook-upplýsinga. Sjónarmið komu hins vegar fram um að Facebook-upplýsingar eða skortur á slíkum upplýsingum gæti orðið til pess að rannsókn máls væri hætt áður en eiginlegt mál hefði hafist. Viðmælandinn hjá Stofnun B sagði:

Maður byrjar kannski að skoða mál og upplýsingar á samfélagsmiðlum benda eindregið til pess að verið sé að fiska í tómri tunnu. Рað getur kannski drepið mál ... eflaust hefur pað gerst. Ég fæ hins vegar voðalega sjaldan að vita af góðu málunum par sem að allt er bara í góðu.

Dá kom fram í viðtalinu sjónarmið um skort á upplýsingum: „Ef pú veiðir ekki neitt pá verður pað aldrei að neinu. Баð getur vel verið að pað sé eitthvað misjafnt í gangi en ef við getum ekki sýnt fram á pað er pað algerlega dautt.“

Hjá Stofnun C kom einnig í ljós að Facebook-upplýsingar hefðu leitt til pess að mál hefði ekki verið hafið eða skoðað sérstaklega.

\subsubsection{Formleg ákvörounarástaða}

Hjá öllum stofnunum var talið að Facebook-upplýsingar kynnu að hafa verið formleg ástæða ákvörðunar. Allar höfðu pær vísað til pess háttar upplýsinga í formlegum úrskurði. Hins vegar hafði Stofnun A einungis byggt á pess konar upplýsingum og vísað til peirra í skriflegum ákvörðunum pegar upplýsingar voru lagðar fram af aðilum máls. Hjá Stofnun $C$ var kannast við að vísað hefði verið til slíkra gagna í skriflegri ákvörðun til stuðnings öðrum upplýsingum: ,Já, en aldrei eitt og sér, alltaf öðru til stuðning. Aldrei eina ákvörðunarástæðan.“

Viðmælendur stofnananna, sem byggðu á Facebook-upplýsingum sem pær sjálfar höfðu aflað, töldu að slíkt ætti sér fremur stað við töku ípyngjandi ákvarðanna en ívilnandi. Í viðtalinu hjá Stofnun D kom eftirfarandi fram: „Ípyngjandi í pví tilviki sem ég er að hugsa um sem er svona stærsta málið okkar sem petta varðar ... eina málið sem ég hef séð par sem gagn hefur ratað í greinagerð, greinagerðin fer fyrir ... og á grundvelli hennar er svo gerður úrskurður.“ Fram kom að mögulega gætu umræddar upplýsingar orðið til ívilnunar. Slíkt væri pá líklegra í peim tilvikum pegar aðilar hefðu sjálfir lagt fram upplýsingar: „Баð er pá í ... málum, ég veit pað ekki. Đað er pá ekki nema viðkomandi aðili sé sjálfur að leggja fram pessi gögn. Ég veit ekki til pess að pað hafi verið gert en pað má vel vera.“ 
Í opinberum úrskurðum hafa ákvarðanir í einhverjum tilvikum verið byggðar að stærstum hluta á upplýsingum sem aflað var á Facebook. Í úrskurði Úrskurdarnefndar atvinnuleysistrygginga og vinnumarkađsadgerda 30. júlí 2015 (14/2015) vísaði Vinnumálastofnun til upplýsinga sem birst höfðu á Facebook-síðu bótapega sem bentu til pess að umræddur aðili uppfyllti ekki skilyrði til atvinnuleysisbóta. Vinnumálastofnun benti á að í málinu lægi fyrir að kærandi hefði áður starfað sem förðunarfræðingur. Dví til stuðnings vísaði stofnunin til útprentana af Facebook-síðu kæranda og skýringarbréfs hennar til stofnunarinnar. Á Facebook-síðu kæranda var meðal annars að finna eftirfarandi færslu: „Er á fullu à taka nidur pantanir!" Bá mátti einnig finna fjölda mynda af verkefnum sem kærandi hafði tekið að sér á áður nefndri síðu. Úrskurðarnefndin komst að peirri niðurstöðu að ekki væri unnt að ráða af gögnum málsins að kærandi hefði tilkynnt Vinnumálastofnun um pessa vinnu sína.

\section{3 Óformleg notkun upplýsinga}

Samkvæmt viðtölum könnuðu opinberir starfsmenn í einhverjum tilvikum upplýsingar á Facebook eða öðrum samfélagsmiðlum við meðferð einstakra mála. Sjaldnast leiddi pess konar könnun á Facebook pó til pess að formlega væri byggt á pessum upplýsingum. Ekki er auðvelt að skilgreina með tæmandi hætti hvað óformleg notkun upplýsinga felur í sér. Hér verður stuðst við neikvæða skilgreiningu hugtaksins og látið nægja að tilgreina: Í óformlegri notkun upplýsinga felst öll notkun peirra önnur en sú að byggja á formlegri ákvörðunarástæðu í máli. Til hagræðingar er eftirfarandi flokkun, sem fyrst og fremst tekur mið af upplýsingum úr viðtölum, sett fram.

\subsubsection{Staðfesting á fyrirliggjandi gögnum eða styrking gruns}

prír viðmælendanna höfðu notað Facebook-upplýsingar til pess að staðfesta gögn í fyrirliggjandi máli. Viðmælandi hjá Stofnun A lýsti pví með eftirfarandi hætti:

Dað gæti verið sú staða að einhverjar upplýsingar vekja upp einhverjar spurningar um áreiðanleika eða eitthvað slíkt ... Stundum er tilfinningin sú að pað séu ekki gefnar allar upplýsingar. Maður er að velta fyrir sér einhverjum leiðum til að fá frekari upplýsingar fram. Dá er kannski verið að reyna að skoða hvað stendur á Facebook hjá viðkomandi. bað getur í einhverjum tilvikum treyst mann í pví sem maður hefur fyrir sér.

Skoðun viðmælanda hjá Stofnun C var sú að upplýsingar á samfélagsmiðlum væru fremur notaðar til pess að staðfesta fyrirliggjandi gögn heldur en að véfengja pau:

Mér finnst svona persónulega að maður geti ekki notað Facebook til að sannreyna neitt. Maður getur notað pað til að byggja undir grun eða pú færð einhvern grun ... Frekar að nota pað að sannreyna að eitthvað sé í lagi en að sannreyna að eitthvað sé ekki i lagi. 


\section{STJÓRNMÁL \& \\ STJÓRNSÝSLA}

Aðrir viðmælendur tiltóku að Facebook-upplýsingar hefðu ekki verið notaðar til sannreyningar nema í mjög takmörkuðum mæli. Viðmælandi Stofnunar B áleit að mögulegt notagildi fælist fremur í að styrkja fyrirliggjandi grun en að sannreyna fyrirliggjandi upplýsingar í máli. „Ég myndi ekki nota sannreyna, petta er yfirleitt til að styrkja grun sem við höfum ... pað sem við erum að leita að í eftirlitinu hjá okkur. Бað kemur yfirleitt ekki mjög afgerandi fram á pessum samfélagsmiðlum.“

Viðmælandi hjá Stofnun D mundi eftir einu tilviki par sem Facebook-upplýsingar voru notaðar til pess að sannreyna fyrirliggjandi gögn í máli með formlegum hætti: „, er líka kannski verið að sannreyna kannski, fá einhverjar frekari upplýsingar, en pað er mjög sjaldgæft að ég sjái gögn í máli hreinlega útskrifuð af Facebook, eða notuð í greinagerð, en ég get samt alveg sagt pér dæmi um slíkt.“

\subsubsection{Betri tilfinning fyrir máli}

Allir viðmælendur höfðu notað upplýsingar, sem aflað var á Facebook, til pess að öðlast betri tilfinningu fyrir málum sem til meðferðar voru. Viðmælandi hjá Stofnun B sagði meðal annars:

Раð hafa líklega komið upp mál par sem pað er algerlega kýrskýrt, opinn Facebook-aðgangur einhvers staðar hjá einhverjum sem er jafnvel með myndir af sér að ... Petta geta verið mjög sterk gögn. Svo getur petta líka bara verið einhvers konar stuðningur eða tilfinning sem er styrkt.

Í viðtalinu hjá Stofnun C kom fram að notkun upplýsinga með petta fyrir augum gæti verið mismunandi eftir starfsmönnum. Par komu einnig fram sjónarmið um að ekki væri hægt að draga of sterkar ályktanir á grundvelli rafrænnar ímyndar einstaklinga:

Betri og aðra tilfinningu, pað hefur alltaf eitthvað að segja, en pað er samt svo misjafnt, maður sér pað alltaf pegar maður er að vinna málin. Maður sér pað um leið að pað er misjafnt hvernig fólk er að nota petta, svo maður verður alltaf að hafa pað í huga. Petta er bara netandlitið hjá fólki.

Sjónarmið viðmælanda Stofnunar D voru einnig pau að framkvæmd gæti verið mismunandi á meðal starfmanna:

Til að fá einhverja tilfinningu fyrir máli, til að sjá viðkomandi, til að átta sig betur á einhverjum aðstæðum, tengslum við eitthvað. Nú erum við oft með fólk sem er mjög tengt í ákveðnum heimum Reykjavíkur og tengsl við aðra og önnur mál, afbrotamenn eða eitthvað slíkt ... Ég hugsa að pað sé alveg gífurlega mismunandi milli aðila hjá okkur hvort petta sé mikið notað eða ekki. 


\subsubsection{Til fyllingar öđrum gögnum}

Tveir viðmælendanna töldu afdráttalaust að Facebook-upplýsingar hefðu verið notaðar til fyllingar öðrum gögnum í máli hjá stofnunum peirra. Framkvæmdinni lýsti viðmælandi hjá Stofnun C með eftirfarandi hætti: „,Við erum með almennar vísbendingar. Við förum svo á Facebook og sjáum að petta styður pað. Pá er petta væntanlega til fyllingar.“

Viðmælandinn hjá Stofnun A viðraði pau sjónarmið að óljóst gæti verið hvenær í rauninni væri byggt á tilteknum atriðum við úrlausn máls:

Petta er kannski skilgreiningaratriði, hvenær maður er að byggja á einhverju ... Petta er kannski ekki beinlínis pannig að maður sé að sækja pangað upplýsingar sem maður byggir síðan úrlausn á heldur getur petta verið manni tilefni til að afla frekari upplýsinga eftir hefðbundnum leiðum eða gefur manni tilefni til að spyrja einhverja spurninga. Hjálpar manni að spyrja réttu spurninga.

Í viðtalinu hjá Stofnun D kom í ljós að almennt væri ekki hægt að byggja ákvörðun eingöngu á Facebook-upplýsingum. Slíkar upplýsingar gæu pó styrkt fyrirliggjandi mál:

Við viljum hafa allt skriflegt. Баð er afar erfitt fyrir okkur að vera að byggja á mikið af upplýsingum sem eru ekki beint í hendi. Ekki nema parna í pessu tilviki parna par sem verið var að úrskurða út af einhverjum svona upplýsingum en pá byggðum við ekki einvörðu á pví en pað styrkti málið klárlega.

Dæmi er um að vísað hefði verið til Facebook-upplýsinga í skriflegum stjórnvaldsákvörðunum samhliða öðrum gögnum. Í úrskurði Úrskurðarnefndar atvinnuleysistrygginga og vinnumarkaðsaðgerða frá 21. desember 2011 (176/2010) var deilt um pað hvort tiltekinn aðili hefði starfað sem sölumaður hjá fyrirtæki á sama tíma og hann páði atvinnuleysisbætur. Mál petta hófst með ábendingu frá ríkisskattstjóra um að viðkomandi hefði pegið laun frá tilteknu fyrirtæki. Við athugun Vinnumálastofnunar á Facebook kom í ljós að aðili hafði starfað par sem sölumaður á sama tíma og hún var skráð atvinnulaus hjá stofnuninni. Umræddar upplýsingar voru síðan staðfestar með pví að óska eftir skýringum og skoða launaseðla viðkomandi aðila fyrir tímabilið.

Í úrskurði Úrskurdarnefndar atvinnuleysistrygginga og vinnumarkaðsaðgerða 24. apríl 2012 (97/2011) lágu fyrir útprent af Facebook-síðu kæranda með fasteignaauglýsingum par sem fram kom að hann inni hjá tiltekinni fasteignasölu. Pá lá fyrir að kærandi hafði bent fólki á að bóka skoðun fasteigna hjá honum í farsíma hans. Framkvæmdarstjóri fasteignasölunnar staðfesti síðan að kærandi hefði reynt fyrir sér hjá fyrirtækinu á pessum tíma.

\subsubsection{Frekari könnun máls}

Hjá öllum stofnununum hafði verið tekin sú ákvörðun að afla mætti frekari gagna á grundvelli Facebook-upplýsinga. Eitthvað fleira purfti pó í flestum tilvikum að koma til 
en Facebook-upplýsingar til pess að hefja mál. Upplýsingar gátu pó haft í för með sér að ákveðið var að kanna mál frekar. Með tilliti til pessa gátu upplýsingar verið bornar undir viðkomandi aðila við formlegri könnun máls. Viðmælandi hjá Stofnun C lýsti gagnaöflun í kjölfar Facebook-upplýsinga á pennan hátt:

Раð kemur eitthvað, pað er pessi grunur og pá kemur petta til fyllingar eða til styrkingar eða eftir pví sem við erum að pæla. Đegar við erum að veita fólki andmælarétt erum við oft að óska eftir frekari gögnum í leiðinni ... Petta er oftast i peim málum sem við erum að veita andmælarétt par sem við erum að skoða petta.

Hjá premur viðmælendanna kom fram að mögulega væri ríkari tilhneiging til pess að hefja könnun pegar upplýsingar bærust frá öðrum aðilum heldur en stjórnvaldið sjálft aflaði. Viðmælandi Stofnunar A sagði: „Фаð er vel pekkt og ekkert óeðlilegt að fólk sé að leggja fram í málum. Aðilar sjálfir eru að leggja fram einhverjar upplýsingar sem aflað var á Facebook og hugsanlega upplýsingar sem peir eru að afla um hinn aðilann eftir peim leiðum.“"

Svipað sjónarmið mátti greina í viðtalinu hjá Stofnun B:

Já, petta getur bæði verið upphaf máls, við erum jafnvel að fá ábendingar af skjáskotum af Facebook, já svo getur petta verið stuðningur við önnur gögn sem við höfum af öðrum stöðum ... Ég myndi segja að petta væri svona algengasta leiðin í málum hjá okkur.

Einnig komu fram sjónarmið um að minni kröfur væru gerðar til upplýsinga, sem leiddu til frekari athugunar, en upplýsinga sem hægt væri að byggja ákvörðun á: „Фað gefur okkur kannski tilefni til að kanna vinnustaðinn en petta er aldrei neitt sem veldur pví að ákvörðun er tekin.“

Viðtalið hjá Stofnun C gaf til kynna að ákveðið hefði verið að kanna mál sérstaklega meðal annars á grundvelli Facebook-upplýsinga sem aðrir hefðu aflað: „Já, pá í formi tilkynninga og pá getur pað mögulega verið grundvöllur fyrir frekari könnun máls. Ég held samt að pað hafi kannski ekki verið eitt og sér pað sem hóf mál. Рað hefur mögulega komið í málið ásamt einhverju öðru og pá er kannski horft til pess.“

Í skriflegum úrskurðum má finna dæmi um rannsókn máls í kjölfar upplýsinga sem aflað hafði verið Facebook. Í úrskurði Úrskurðarnefndar atvinnuleysistrygginga og vinnumarkаðsaðgerða 22. september 2011 (188/2010) kom fram að eftirlitsdeild Vinnumálastofnunar hefði gert athuganir á Facebook-síðu. Баð var gert á grundvelli upplýsinga sem höfðu borist stofnuninni um að viðkomandi væri við vinnu samhliða pví að piggja atvinnuleysisbætur. Við skoðun á Facebook-síðu kom í ljós að umræddur aðili hefði boðið upp á förðunarpjónustu ásamt pví að selja snyrtivörur. Pá hafi viðkomandi auglýst eftir íslenskri hönnun í umboðssölu. Í kjölfarið hefði eftirlitsdeild Vinnumálastofnunar farið á vettvang og gert athugun á starfsstöð verslunarinnar. Á grundvelli peirrar rannsóknar 


\section{STJÓRNSÝSLA}

var viðkomandi aðili beittur viðurlögum. Úrskurðarnefndin felldi hins vegar úr gildi ákvörðun Vinnumálastofnunar par sem ekki var nægjanlega gætt að andmælarétti við töku ákvörðunarinnar.

Í úrskurði Úrskurðarnefndar atvinnuleysistrygginga og vinnumarkaðsaðgerda 5. desember 2012 (184/2011) kom í ljós við athugun á Facebook-síðu að tiltekinn aðili hefði selt málverk á sama tíma og hann páði atvinnuleysisbætur. Рað gaf Vinnumálastofnun tilefni til pess að athuga mál mannsins frekar.

\subsubsection{Aঠ hafa upp á einstaklingum}

Við skoðun á mögulegum notum upplýsinga á Facebook til pess að hafa uppi á fólki kom fram að allir viðmælendur töldu líklegt að slíkt hefði í einhverjum tilvikum verið reynt. Viðmælandinn hjá Stofnun B sagði að stofnunin notaðist fyrst og fremst við aðrar upplýsingar til pess að hafa uppi á fólki: „Баð getur vel verið, en aftur við erum með pað mikið af upplýsingum um petta fólk. Við erum með heimilisföng, símanúmer, netföng. Við erum með allan pakkann. Баð er yfirleitt ekki erfitt að ná í fólk ef maður reynir.“

Í viðtalinu hjá Stofnun $C$ var vísað til pess að reynt hefði verið að hafa uppi á fólki með pví að afla upplýsinga á Facebook. Viðmælandinn taldi pó að slíkt hefði ekki gefist sérlega vel: „Ég veit að við höfum gert pað til að leita að fólki. Ég man hins vegar ekki eftir pví að pað hafi tekist. Fólk er náttúrulega ekki með heimilisföng venjulega skráð.“ рá kom fram sú skoðun að Facebook-notkun, með pað fyrir augum að hafa uppi á einstaklingum, væri ef til vill vægara úrræði en önnur sem stóðu stofnuninni til boða:

एað er oft mjög erfitt að ná í fólk og fólk vill oft ekki endilega að við náum í pað. Maður reynir ýmislegt. Ein leið sem við höfum til að birta ákvarðanir með bréfi er að senda lögreglu með pað og maður reynir að forðast pað í lengstu lög. Svo maður reynir venjulega flest áður.

Viðmælandi Stofnunar D nefndi að Facebook-upplýsingar gætu nýst við að staðsetja einstaklinga:

Ég hugsa að pað sé kannski algengt að einhverju leyti pegar við erum að reyna að boða fólk og pað mætir ítrekað ekki, hvort pað sé kannski bara flutt erlendis eða eitthvað slíkt. Eins líka pegar mál eru í vinnslu og pað næst ekki í fólk og málin eru komin á eitthvað pvingunarstig fyrir ... Við höfum staðið frammi fyrir pví að lögmenn hafa komið og sagt að viðkomandi væri í fríi erlendis svo var viðkomandi látinn sama dag.

\subsubsection{Annad}

Við greiningu viðtalanna komu ákveðnar vísbendingar í ljós um pað að stjórnvöld notuðu upplýsingar á samfélagsmiðlum til pess að styrkja trú á pví að niðurstaða í máli væri efnislega rétt. Viðmælandi hjá Stofnun A sagði: „Maður er að velta fyrir sér einhverjum 
leiðum til pess að fá frekari upplýsingar fram. •á er kannski verið að reyna að skoða hvað stendur á Facebook hjá viðkomandi. Đað getur í einhverjum tilvikum treyst mann í pví sem maður hefur fyrir sér.“

Hvað petta varðar kunna upplýsingar að nýtast til pess að leiða menn áfram og stuðla óbeint að efnislega réttri niðurstöðu pó svo að ekki sé byggt á peim formlega:

petta er kannski ekki eitthvað sem er síðan hægt að segja í einhverri stjórnsýsluákvörðun sem maður er að byggja á. Detta er frekar eitthvað svona til að leiða mann áfram og treystist í pví að maður sé að gera rétt. Đví auðvitað eru petta ekki áreiðanlegar upplýsingar.

Sambærilegt sjónarhorn var hægt að greina í viðtölum hjá Stofnun C. Par kom fram að Facebook-upplýsingar hefðu í einhverjum tilvikum gagnast við að afskrifa grunsemdir:

Pegar við tökum ívilnandi ákvarðanir eru pær mjög sjaldan skriflegar ... Ég man eftir pví að við höfum notað upplýsingar á Facebook í ívilnandi ákvörðun. Pá hefur verið einhver grunur um að ekki væri allt í lagi, svo höfum við farið á Facebook og eftir pað höfum við hugsað, nei, petta er örugglega allt í lagi. Баð hefur alveg gerst ... Stundum er maður bara ekki viss um að pað sé einhver ástæða til að skoða petta. Svo fer maður á Facebook og sér fullt af myndum af ... og jafnvel myndbönd og allt virðist mjög venjulegt. Eins og pað getur verið á netinu pá purfum við kannski ekkert að skoða petta frekar.

Fram kom að Stofnun B hafði aflað upplýsinga á Facebook við endurskoðun mála: „,Рað hafa komið upp mál par sem við höfum tekið ákvörðun, seinna meir hefur okkur síðan borist beiðni um endurupptöku. Við höfum skoðað málið jafnvel enn betur eftir pað og pá fengið upplýsingar á Facebook.“

Stofnun A hafði meðal annars notað Facebook við opinberar ráðningar: „Eitt sem ég hef alveg skotið fram hjá, kannski í tengslum við ráðningar á fólki í starf, hafi maður kannski athugað hvað er ekki bara á Facebook heldur bara vefviðveru.“

Hjá Stofnun D kom fram að Facebook-upplýsingar hefðu mögulega verið nýttar til pess að auðkenna eða bera kennsl á fólk: „, Pannig að við í okkar vinnu, er petta meira til uppfyllingar, til að svara forvitni, til að átta sig á tengslum, mögulega til að átta sig á pví hvernig fólk lítur út, pegar pú átt von á pví í viðtal eða eitthvað slíkt, en ekki til að byggja á."

\section{Umræður og samantekt}

Tilkoma samfélagsmiðla hefur orðið til pess að einstaklingar birta persónuupplýsingar á netinu par sem auðvelt er að nálgast pær (Ellison \& boyd, 2014). Allar stofnanirnar, sem tóku pátt í rannsókninni, nýttu sér slíkar upplýsingar. Í pví samhengi höfðu pær allar aflað upplýsinga á Facebook að eigin frumkvæði. Pessar niðurstöður eru í samræmi 
við eldri rannsóknir um að sífellt sé algengara að opinberir aðilar nýti sér upplýsingar á samfélagsmiðlum við eftirlitsstarfsemi (Barker, Barker, Bormann \& Neher, 2013; Lyon, 2007; Orsburn, 2012). Allir viðmælendur könnuðust við að hafa móttekið slíkar upplýsingar frá almennum borgurum, annars vegar frá aðilum máls og hins vegar frá öðrum aðilum í formi tilkynninga.

Aðeins ein stofnananna hafði sérstaka Facebook-síðu. Tvær peirra höfðu útbúið sérstakan Facebook-aðgang til pess að afla upplýsinga um einstaklinga. Algengast var að starfsmenn stofnananna nálguðust upplýsingar um einstaklinga á eigin Facebook-aðgangi.

Eins og fram hefur komið getur pað oltið á friðhelgisstillingum einstaklinga hversu aðgengilegt efni peirra er. Ekki er hægt að útiloka að starfsmaður geti notið ríkari aðgangs að upplýsingum á tiltekinni Facebook-síðu á grundvelli sameiginlegra tenginga eða vinatengsla en stofnun hafði. Athyglisvert er að skoða pessar niðurstöður í ljósi pess hvort umræddar upplýsingar geti talist opinberar í skilningi ádur nefndra persónuverndarlaga.

Tafla 1 sýnir svör viðmælenda um hvernig miðlun og móttöku upplýsinga var háttað hjá stofnunum.

Tafla 1. Móttaka og miðlun upplýsinga.

\begin{tabular}{|c|c|c|c|c|c|}
\hline Facebook-upplýsingar & Stofnun A & Stofnun B & Stofnun C & Stofnun D & Samtals \\
\hline $\begin{array}{l}\text { Öflun upplýsinga að eigin } \\
\text { frumkvæði }\end{array}$ & $\checkmark$ & $\checkmark$ & $\sqrt{ }$ & $v$ & $4^{*}$ \\
\hline $\begin{array}{l}\text { Móttaka upplýsinga frá } \\
\text { ađilum máls }\end{array}$ & $v$ & & $v$ & $v$ & 3 \\
\hline $\begin{array}{l}\text { Móttaka upplýsinga frá } \\
\text { öđrum en ađilum máls }\end{array}$ & & 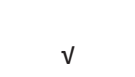 & $\sqrt{ }$ & $v$ & 3 \\
\hline $\begin{array}{l}\text { Móttaka upplýsinga frá } \\
\text { öđrum stjórnvöldum }\end{array}$ & & & & „mögulega“ & 0 \\
\hline $\begin{array}{l}\text { Miðlun upplýsinga til annarra } \\
\text { stjórnvalda }\end{array}$ & $\checkmark$ & & $v$ & & 2 \\
\hline $\begin{array}{l}\text { Er stofnunin með opinbera } \\
\text { Facebook-síðu? }\end{array}$ & & $\checkmark$ & & & 1 \\
\hline $\begin{array}{l}\text { Er stofnunin með sérstakan } \\
\text { aðgang til að afla upplýsinga? }\end{array}$ & & $\checkmark$ & $v$ & & 2 \\
\hline Samtals & 3 & 4 & 5 & 3 & 15 \\
\hline
\end{tabular}

* Tölurnar sýna fjölda jákvæðra tilvika.

Fram kom að stofnanirnar nýttu sér upplýsingar á Facebook við formlega notkun á takmarkaðan hátt enda væri almennt ekki hægt að byggja á pess háttar gögnum einum og sér. Sú niðurstaða er í nokkru samræmi við rannsóknir sem framkvæmdar hafa verið á afstöðu manna til trúverðuleika upplýsinga á samfélagsmiðlum (Curiel, 2013). 
Í peim tilvikum pegar byggt var á slíkum upplýsingum voru pær almennt bornar undir viðkomandi aðila og/eða staðfestar á annan hátt. Í skriflegum úrskurðum hefur verið byggt á upplýsingum, sem aflað var á Facebook, sem ákvörðunarástæðu - bæði einum og sér og til stuðnings öðrum upplýsingum. Gat pað meðal annars oltið á pví hvort andmælaréttur hefði verið veittur við meðferð máls. Ýmislegt bendir pví til pess að stofnanir gæti almennt að málsmeðferðareglum stjórnsýslulaga pegar formlega er byggt á slíkum gögnum.

Enginn viðmælendanna vildi kannast við að mál hefði verið fellt niður á grundvelli Facebook-upplýsinga. Slíkar upplýsingar eða skortur á slíkum upplýsingum gat hins vegar orðið til pess að mál var ekki kannað frekar. Í ljós kom að nokkuð fín lína gat verið á milli pess að hefja könnun máls og að hefja formlegt stjórnsýslumál.

Niðurstöður pessarar rannsóknar staðfesta að upplýsingar á Facebook eru notaðar í eftirlitsskyni með einstaklingum hérlendis. Við skoðun á útbreiðslu Facebook hér á landi (Jóhanna Gunnlaugsdóttir, 2014) og magni og eðli peirra upplýsinga sem par er að finna (Ellison \& boyd, 2014) ætti sú staðreynd ekki að koma á óvart.

Tafla 2 sýnir svör viðmælenda pegar spurt var um hvernig formlegri notkun upplýsinga hjá stofnununum væri háttað.

Tafla 2. Formleg notkun upplýsinga

\begin{tabular}{lccccc}
\hline Facebook-upplýsingar & Stofnun A & Stofnun B & Stofnun C & Stofnun D & Samtals \\
\hline Upphaf stjórnsýslumáls & & & $\checkmark$ & & $1^{*}$ \\
\hline Niđurfelling stjórnsýslumáls & & & & & \\
\hline Formleg ákvörđunartaka & $\sqrt{ }$ & $\checkmark$ & $\checkmark$ & $\checkmark$ & 4 \\
\hline Samtals & 1 & 1 & 2 & 1 & 5 \\
\hline
\end{tabular}

* Tölurnar sýna fjölda jákvæðra tilvika.

Að mati viðmælenda var notagildi upplýsinga, sem aflað var á Facebook, almennt ríkara pegar pær voru nýttar með óformlegum hætti. Óformleg notkun upplýsinga var algengari en formleg notkun. Allir viðmælendur höfðu notað Facebook-upplýsingar til pess að öðlast tilfinningu fyrir máli sem var til meðferðar. Prír af viðmælendunum fjórum sögðust hafa notað pess háttar upplýsingar til pess að staðfesta fyrirliggjandi gögn eða styrkja grun. Í ljós kom að hjá öllum stofnununum hefði í einhverjum tilvikum verið leitast við að hafa uppi á einstaklingum á grundvelli Facebook-upplýsinga.

Hjá öllum stofnununum hafði verið ákveðið að afla frekari gagna á grundvelli Facebook-upplýsinga. Einungis tveir viðmælendanna vildu kannast við að hafa notast við slíkar upplýsingar til fyllingar öðrum gögnum í máli. Ákveðin sjónarmið komu fram í pví samhengi að í raun gæti verið skilgreiningaratriði hvenær væri byggt á tilteknum gögnum. Í einhverjum tilvikum kom fram að Facebook hefði verið notað til pess að bera kennsl á fólk sem boðað hefði verið í viðtöl. Í viðtölum kom einnig fram að Facebook hafði verið nýtt í sambandi við mannaráðningar hjá einhverjum stofnananna. Dess háttar 


\section{STJÓRNSÝSLA}

notkun er í samræmi við rannsóknarniðurstöður um notkun samfélagsmiðla í pessu skyni (Spraque, 2008).

Tafla 3 sýnir svör viðmælenda við fyrirspurnum um óformlega notkun upplýsinga sem aflað var á Facebook.

Tafla 3. Óformleg notkun upplýsinga.

\begin{tabular}{|c|c|c|c|c|c|}
\hline Facebook-upplýsingar & Stofnun A & Stofnun B & Stofnun C & Stofnun D & Samtlas \\
\hline $\begin{array}{l}\text { Til bess að staðfesta } \\
\text { fyrirliggjandi gögn }\end{array}$ & v & v & & $v$ & $3^{*}$ \\
\hline $\begin{array}{l}\text { Til pess ađ fá betri tilfinningu } \\
\text { fyrir máli }\end{array}$ & v & v & v & $v$ & 4 \\
\hline Til fyllingar öđrum gögnum & „mögulega“ & & v & $v$ & 2 \\
\hline $\begin{array}{l}\text { Til grundvallar frekari } \\
\text { könnunar }\end{array}$ & v & v & v & v & 4 \\
\hline $\begin{array}{l}\text { Til pess að hafa upp á } \\
\text { einstaklingum }\end{array}$ & v & v & v & v & 4 \\
\hline Samtals & 4 & 4 & 4 & 5 & 17 \\
\hline
\end{tabular}

* Tölurnar sýna fjölda jákvæðra tilvika.

\section{Lokaorð}

Niðurstöðurnar sýna að upplýsingar á Facebook geti haft pýðingu fyrir úrlausn stjórnsýslumála bæði með beinum og óbeinum hætti. Rannsóknin leiddi í ljós að upplýsingar, sem aflað var á Facebook í tengslum við meðferð tiltekinna mála, rötuðu einungis í undantekningartilvikum í skriflega úrskurði. Ýmislegt bendir til pess að notkun pessara upplýsinga sé oftar óformlegs eðlis og notagildi peirra ef til vill mest við pess háttar hagnýtingu. Eðli málsins samkvæmt geta dómar og úrskurðir eingöngu veitt takmarkaða leiðsögn hvað petta varðar.

Rannsókn sem pessi getur ekki staðfest með óyggjandi hætti hver hin raunverulega notkun umrædda upplýsinga er. Hún getur ekki heldur útskýrt, nema að litlu leyti, hvort og hvaða áhrif pessi notkun hefur á niðurstöður flestra mála. Pó er unnt að draga ályktanir af peim vísbendingum sem fram hafa komið.

Í fyrsta lagi er hægt að slá pví föstu að upplýsingar á samfélagsmiðlum séu notaðar með formlegum og óformlegum hætti í opinberri stjórnsýslu hérlendis á lægra stigi (micro-stigi).

Í öðru lagi leiddi rannsóknin í ljós að Facebook kann að vera gagnlegt eftirlitsúrræði fyrir sumar stofnanir í peim tilgangi að komast á sporið varðandi möguleg lögbrot. Mismunandi var eftir stofnunum hversu gagnlegar slíkar upplýsingar gátu verið. Notagildi Facebook-upplýsinga virtist ríkara peim hjá stofnunum sem pjónuðu skýru eftirlitshlutverki en hjá eiginlegum úrskurðarstofnunum. 
Óskandi er að rannsóknin geti lagt grunn að frekari rannsóknum um notkun samfélagsmiðla við ákvarðanatöku stjórnvalda. Ekki hafa verið framkvæmdar rannsóknir á raunverulegri tíðni ófomlegrar notkunar upplýsinga á samfélagsmiðlum og raunverulegri pýðingu slíkrar notkunar fyrir úrlausn tiltekinna mála. Pá hafa ekki verið gerðar rannsóknir á notkun löggæslustofnana á samfélagsmiðlum í págu sakamálarannsókna hér á landi. Slíkar rannsóknir gætu haft hagnýtt gildi, ekki síst fyrir pá sem starfa við rannsókn sakamála og refsivörslu. Í tengslum við efnissviðið væri áhugavert að rannsaka nánar lagalegar heimildir til vinnslu og varðveislu persónupplýsinga sem aflað er einhliða af stjórnvöldum. Pá væri einnig áhugavert að kanna frekar raunverulegt vægi slíkra gagna við sönnunarfærslu á dóms- og stjórnsýslustigi.

Ekki er hægt að útiloka að hluta pess árangurs, sem náðst hefur í opinberu eftirliti, með öflun upplýsinga á Facebook, megi rekja til pess að notendur virðast ekki vera fyllilega meðvitaðir um tilvist hins rafræna eftirlits. Vaxandi notkun stjórnvalda á samfélagsmiðlum í pessu skyni, kann að hafa áhrif á hvernig einstaklingar umgangast miðlana og hvaða upplýsingum peir deila. Aukin vitneskja almennings um tilteknar eftirlitsaðferðir og aukin öryggishegðun er mögulega til pess fallin að draga úr notagildi opinbers eftirlits á samfélagsmiðlum. Slíkt væri í samræmi við niðurstöður rannsókna sem gerðar hafa verið á öryggishegðun Facebook-notenda (Debatin, Lovejoy, Horn \& Hughes, 2009). Hér verður látið liggja á milli hluta hvort slík próun yrði til góðs eða ills. Óhætt er pó að halda pví fram að pær miklu og vaxandi framfarir, sem hafa og munu eiga sér stað á sviði upplýsingatækni, eiga eftir að breyta hugmyndum manna um einkalíf og einkalífsvernd í framtíð og til frambúðar.

\section{Heimildaskrá}

April, P. S., Levin, A. og Del Riego, A. (2012). „Blurred Boundaries; Social Media Privacy and the Twenty-First-Century Employee", American Buisness Law Journal 49, 63-124.

Almer, T. , Fuchs, C., Kreilinger, V. og Sevignani, S. (2014). „Social Networking Sites in the Surveillence Society: Critical Perspectives and Empirical Findings“, í P. Lang (ritstj) Media Surveillance and Identity: Social Perspectives, (bls. 49-69). New York.

Barker, M., Barker D., Bormann, N. og Neher, K. (2013). Social media marketing: A strategic approach. International Edition: South-Western, Cengage Learning.

Bjarki Valtýsson (2012) „Facebook as a Digital Public Sphere: Processes of Colonization and Emancipation", Triple C: Communication, Capitalism \& Critique. Open Acess Journal for a Global Sustainable Information Society 10(1), 77-91.

Braun, V. og Clarke, V. (2013). Successful Qualitative Research: A Practical Guide for Beginners. Los Angeles: Sage Publications.

Bucher, T. (2012) „Want to be on the Top? Algorithmic Power and the Threat of Invisibility on Facebook", New Media Society 14(7), 1164-1180.

Charmaz, K. (2014). Constructing Grounded Theory (2. útg.). London: Sage Publications Ltd.

Cockfield, A. J. (2002) „Who whatches the watchers? Examining the Relationship between Government and private sector surveillance“. Sótt af http://post.queensu.ca/ ac24/QueensLJArticle.pdf.

Debatin, B., Lovejoy, J. P., Horn, A., og Hughes, B. N. (2009). „Facebook and Online Privacy: Attitudes, Behaviors, and Unintended Consequences", Journal of Computer-Mediated Communication 15, 83-108.

Ellison, N. B. \& boyd, d. (2013). „Sociality through Social Network Sites“, í W. H. Dutton, (ritstj.), The Oxford Handbook of Internet Studies (bls. 151-172). Oxford: Oxford University Press. 
Facebook (2016) „Government Request Report“. Sótt af https://govtrequests.facebook.com/

Fuchs, C. (2011) „New Media, Web 2.0 and Surveillance“, Sociology Compass, 5(2), 134-147.

Glaser, B. G. og Strauss, A. L. (1967). The Discovery of Grounded Theory: Strategies for Qualitative Research. Chicago: Aldine Publishing Company.

Gorman G. E. og Clayton, P. (2005). Qualitative Research for the Information Professional: A Practical Handbook (2. útg). London: Facet Publishing.

Haggerty, K. D., Wilson, D. Og Smith, G. J. D. (2011). „Theorizing Surveillance in Crime Control“, Theoretical Criminology 15(3), 231-237.

Helga Jónsdóttir (2013). „Viðtöl í eigindlegum og megindlegum rannsóknum“, í Sigríður Halldórsdóttir (ritsti.), Handbók i aðfferdafrađi rannsókna (bls. 137-153). Akureyri: Háskólinn á Akureyri.

Hennink, M., Hutter, I. og Bailey, A. (2011). Qualitative Research Methods. Los Angeles: Sage Publications. Jóhanna Gunnlaugsdóttir (2014). „Skjámenning og netnotkun vegna einkaerinda á vinnutíma“, Ritið: Tímarit Hugvísindastofnunar Háskóla Íslands 3, 85-113.

Kammerer, D. (2009). „Police Use of Videosurveillance in Germany from 1956: Management of Traffic, Repression of Flows, Persuasion of Offenders", Surveillance \& Society 6(1), 43-47.

Katrín Blöndal og Sigríður Halldórsdóttir (2013). „Úrtök og úrtaksaðferðir í eigindlegum rannsóknum“, í Sigríður Halldórsdóttir (ritsti.), Handbók i aðferða afrađi rannsókna (bls. 129-136). Akureyri: Háskólinn á Akureyri.

Lewis, K., Kaufman, J. og Christakis, N. (2008). „The Taste for Privacy: An Analysis of College Student Privacy Setting in an Online Social Network “, Journal of Computer-Mediated Communication 14, 79-100.

Lyon, D. (2007). Surveillance Studies: An Overview. Oxford: Polity Press.

Lög nr. 77/2000 um persónuvernd og meðferð persónuupplýsinga.

Már Einarsson og Jóhanna Gunnlaugsdóttir (2014). „Samfélagsmiðlar hjá ríkisstofnunum á Íslandi: Notkun, hlutverk og markmið“, Stjórnmál og stjórnsýsla 10(2), 317-337.

Osborn, E. M. (2012). Social media business equation: Using online connections to grow your bottom line. Boston, MA: Course Technology.

Palys, T. (2008). „Purposive Sampling“, í L. M. Given (ritstj.), The Sage Encyclopedia of Qualitative Research Methods (bls. 697-698). California: Sage.

Saunders, M., Lewis, P. og Thornhill A. (2009). Research Methods for Business Students (5. útg.). Essex: Pearson Education Limited.

Schwandt, T. A. (2007). The Sage Dictionary of Qualitative Inquiry (3. útg). Los Angeles: Sage Publications. Silverman, D. (2013). Doing Qualitative Research (4. útg.). London: Sage Publication.

Sigurður G. Hafstað (2016). Eftirlitsstarfsemi bins opinbera. Facebook sem verkfari til eftirlits. Óbirt MPA-ritgerð: Reykjavík: Háskóli Íslands, Stjórnmálafræðideild.

Sigrún Jóhannesdóttir (2015). Persónwverndarlög: Skýringarit. Reykjavík: Fons Juris.

Sprague, R. (2008). „Rethinking Information Privacy in an Age of Online Transparency“, Hofstra Labor and Employment Law Journal, 25, 395-417.

Stjórnsýslulög nr. 37/1993.

Strandburg, K. J. (2011). "Home, Home on the Web and Other Fourth Amendment Implications and Technosocial Change", Maryland Law Review, 3, 614-680.

Unnur Guðrún Óttarsdóttir (2013). „Grunduð kenning og teiknaðar skýringarmyndir“, i Sigríður Halldórsdóttir (ritsti.), Handbók i a đferdafradi rannsókna (bls. 361-375). Akureyri: Háskólinn á Akureyri.

Welsh, B. C. og Farrington, D. P. (2008). „Effects of closed circuit Television Surveillance on Crime“, Campbell Systematic Reviews, 17. Sótt af https://campbellcollaboration.org/media/k2/attachments/1048_R.pdf.

Úrskurðir

Úrskurðir Úrskurðarnefndar um atvinnuleysistryggingar og vinnumarkaðsaðgerðir.

Úrskurður Úrskurđarnefndar um atvinnuleysistryggingar og vinnumarkaðsaðgerđir frá 3. desember 2015 mál nr. $(53 / 2015)$. 
Úrskurður Úrskurđarnefndar um atvinnuleysistryggingar og vinnumarkaðsadgerdir frá 30. júlí 2015 mál nr. $(14 / 2015)$.

Úrskurður Úrskurðarnefndar um atvinnuleysistryggingar og vinnumarkaðsadgerdir frá 1. júlí 2015 mál nr. (87/2014).

Úrskurður Úrskurdarnefndar um atvinnuleysistryggingar og vinnumarkaðsadgerdir frá 25. nóvember 2014 $(19 / 2014)$.

Úrskurður Úrskurððarnefndar um atvinnuleysistryggingar og vinnumarkaðsaðgerdir frá 24. apríl 2012 (97/2011).

Úrskurður Úrskurðarnefndar um atvinnuleysistryggingar og vinnumarkaðsadgerð̀a frá 22. september 2011 mál nr. $(188 / 2010)$.

Úrskurður Úrskurðarnefndar um atvinnuleysistryggingar og vinnumarkaðsaðgerðir frá 5. desember 2012 $(184 / 2011)$.

Úrskurður Úrskurðarnefndar um atvinnuleysistryggingar og vinnumarkaðsaðgeròir frá 26. maí 2011 (131/2010).

Úrskurður Úrskurdarnefndar um atvinnuleysistryggingar og vinnumarkadsadgerdir frá 7. apríl 2011 mál nr. $(109 / 2010)$.

Úrskurðir Úrskurðarnefndar samkvæmt lögum um hollustuhætti og mengunarvarnir:

Úrskurður Úrskurঠarnefndar samkvamt lögum um hollustubatti og mengunarvarnir 8. apríl 2011 (6/2010). 
